\title{
The Indonesian Family Welfare Guidance Programme (PKK) and the Revitalisation of Corporatist State Organisations: A Case Study of the Mobilisation of Support for Dewanti Rumpoko in the 2017 Batu Municipal Election $^{1}$
}

\author{
Muhammad Fadzryl Adzmy and Fikri Disyacitta
}

Received: 25 August 2017 | Accepted: 12 March 2018 | Published: 26 March 2018

\begin{abstract}
This article is intended to explore the use of the Family Welfare Guidance Programme (Pembinaan Kesejahteraan Keluarga, PKK) in the Municipality of Batu by one candidate as a means of mobilising political support during the 2017 municipal election. Within the current democratic climate, it is interesting to examine how the PKK, as a state corporate organisation that should ideally remain politically neutral, can be exploited to mobilise political support. The main argument of this article is that several factors, including deeprooted hierarchies, top-down instruction, and clientelism enabled the PKK to be exploited by the incumbent in her mobilisation of political support. To sidestep the principle of neutrality and support the incumbent, PKK cadres used various means during the municipal election. The data for this article was collected using the qualitative approach, with in-depth interviews and participatory observation over the course of the Batu municipal election (JanuaryFebruary 2017).
\end{abstract}

Keywords: corporatist state organisations, political brokerage, PKK, clientelism, regional elections, Dewanti Rumpoko

\section{Introduction}

This article attempts to explore the use of the Family Welfare Guidance Programme (Pembinaan Kesejahteraan Keluarga, PKK) as a state corporate organisation in mobilising voter support during the 2017 Batu municipal elections. Furthermore, this article is

\footnotetext{
The authors would like to express their gratitude to PolGov, Universitas Gadjah Mada, and the Coral Bell School of Asia Pacific Affairs, Australia National University, for providing them with full support during the data collection process as well as valuable input during the writing of this article.
} 
intended to enrich understandings of the connections between a state corporate organisation (PKK) and a political mechanism (regional elections). In this current democratic era, PKK has been visualised as a women's organisation working with the government to promote social welfare, beginning at the family level. However, looking at the situation during the authoritarian New Order era, the PKK was once used as a political tool and a means of ideological control (Suryakusuma, 2011), and thereby provided the regime with significant support. Historically, the state corporate organisation model was in Indonesia introduced during the British occupation, and continued under the Dutch through Indische Staatsblad 1854 (Nurcholis, 2016). Under the New Order regime, Indonesia used corporatist state organisations to control various social groups, including labourers and farmers. Women, particularly those in rural areas, were co-opted through the PKK (Reeve, 1985). ${ }^{2}$ Although the PKK programme was initiated by the Old Order regime and intended initially as a highly populist organisation, under the New Order its activities were informed and influenced by the development targets prioritised by the regime (Rahayu, 2005).

Through Decree of the Minister of Domestic Affairs No. SUS/3/6/12, dated 27 December 1972, the government changed the name of the PKK programme from Family Welfare Education (Pendidikan Kesejahteraan Keluarga) to Family Welfare Guidance (Pembinaan Kesejahteraan Keluarga). This name change has been argued to represent state hegemonisation of women's movements in Indonesia (Handayani, Parimartha, Sukesi, \& Andika, 2008). The PKK officially became a strategic partner of the government in its development programmes through the fourth Five-Year Development Plan (GBHN Pelita IV) enacted in 1984 (Rahayu, 2005). Efforts to ensure the loyalty of corporatist state organisations

Reeve's study, undertaken between 1969 and 1971, does not categorise the PKK as a corporate state organ for women. The PKK, as a channel and organisation for women, was only explored - in fact, received a sub-chapter discussing it—by MacIntyre ("Organising Interest", 3-6) and Rosser et al. ("Indonesia: The Politics", 2). 
such as PKK were reaffirmed through Law No. 8 of 1985 regarding Social Organisations. Although neither PKK nor the women's organisation Dharma Wanita were social organisations, having been established by the government, the elucidation of Article 1 required corporate organisations to follow the same standards as social organisations: i.e. use Pancasila as their sole guideline as they promote national development. ${ }^{3}$

Such efforts to guarantee PKK's loyalty through various pieces of legislation were not only effective for mobilising women in the implementation of the 10 Key PKK Programmes, which was central to the New Order's development programmes. Furthermore, during elections, PKK was frequently used to mobilise women in political campaigns and gather votes for the Golkar Party (Fauzia, as cited in Burhanudin \& Fathurahman, 2004). In other words, PKK functioned as a political broker during elections, ensuring that women-particularly married ones-remained loyal supporters of the ruling Golkar Party (Marcoes, as cited in Robinson \& Bessell, 2002). This remains reflected in the organisation's top-down structure and the clientelistic relations contained within it (Handayani et al., 2008).

Following the end of the New Order, corporatist state organisations did not disappear from Indonesia. PKK persevered under the new regime, under the name Pemberdayaan dan Kesejahteraan Keluarga (Family Empowerment and Welfare). Furthermore, where under the New Order government the PKK was used as a political tool for the government, under the new democratic regime it became expected to remain politically neutral. According to Dewi (2015), a researcher with the Indonesian Institute of Sciences, although PKK remains under the purview of the Ministry of Domestic Affairs, it has begun to take a more active role in promoting women's political rights (rather than becoming a passive political tool). Elsewhere, Dewi (2007) wrote that, since

Law No. 8 of 1995 regarding Social Organisations. 
the New Order, the PKK has been expected to remain independent of outside political interests and thereby focus its efforts on empowering women to actively promote social betterment. Dewi's findings appear relevant to research conducted in Malang in the lead-up to the 2013 gubernatorial election in East Java, which found that the local PKK had worked together with anti-corruption NGOs to convince women - through prayer groups and market activitiesto reject and oppose the practice of money politics by candidates (Malik et al., 2013).

However, despite findings suggesting that PKK has been politically independent since the fall of the New Order, researchers have shown that it has not remained neutral in politics - particularly in regional elections. Research conducted by Soetjipto and Adelina (2013) in four villages in Java shows that PKK has been mobilised in political campaigns by various political parties-rather than only the Golkar Party, as previously-in the lead-up to elections. Parties in power, as well as incumbents' wives, have mobilised women through the PKK, using clientelistic approaches to collect votes. Elsewhere, Sari (as cited in Wulan, 2008) has shown that PKK, despite being expected to facilitate poor rural women in policymaking and women's empowerment processes, has exploited local people's ignorance to promote the interests of state elites in West Java.

According to Dewi $(2015,2007)$ and Sari (ibid), feminist and women's movement perspectives have been highlighted in measuring PKK's activity in politics, and thus many researchers have focused on the extent of members' knowledge and awareness of gender issues and gender mainstreaming. Meanwhile, research by Soetjipto and Adelina (2013) only touched on the use of PKK networks in regional elections, without further considering the strategies and methods used for mobilisation. It is interesting to see how, more than nineteen years after the end of the New Order government, there are indications that PKK has again — as in the New Orderbecome used as a means of mobilising voter support. In the 2017 
Batu municipal election, a candidate utilised PKK networks in her political campaign. Furthermore, unlike the study by Malik et al. in Malang, this article argues that the PKK in Batu has become trapped in clientelistic relations with the incumbent, and as such has not retained its independence as in Malang.

In this article, the researcher relies on two key concepts for its comprehensive analysis of the use of PKK in politics. First is the concept of state corporate organisation. State corporatism is mostly researched based on the experiences of rightist authoritarian countries such as Spain and Portugal (under fascism) and Latin America (under dictatorial rule) (Carrasco, 1993). State corporatism may be defined in one of two ways. Manoilesco (Milne, 1983) defines state corporatism as the organisation of citizens who share the same interests as the state into interest groups with equal social power. Meanwhile, Schmitter (as cited in Gerber, 1993) defines it as the organisation of citizens - either by the government or with government legitimisation - into hierarchy and non-competitive interest groups that are subordinate to the government and receive special benefits, with membership in these groups being compulsory for all people of a certain profession or social category.

According to Wiarda (2009), the establishment of corporatist state organisations is intended to guarantee members' loyalty to the ruling regime as well as maintain state control of organisational activities at the social level. However, it should be noted that Schmitter makes a critical note about understanding the dynamics of corporatist state organisations. When authoritarian states transition into democracies, corporatist state organisations should ideally transform into corporatist social organisations that are more independent of state power. Through these two definitions, state corporatism can be understood as the hierarchy organisation of citizens by the government in support of the ruling regime, with special rights being given to a limited number of people (generally those in charge of these organisations).

Second is the concept of political brokerage. Electoral 
processes can not readily be separated from candidates' various endeavours and strategies used to win elections, including the use of political brokerage to gather voter support. Wang and Kurzman (2007) identify brokers as agents who ease candidates in approaching potential voters. Aspinall and Sukmajati (2015) add that brokers occupy have an important function for candidates. As constituencies cover expansive areas and voters are large in number, candidates have limited ability to meet directly with their constituents, and as such they require agents who can help and represent them in their campaigns, and introduce them and their programmes to constituents. As such, brokers play a vital role in campaign activities.

In their research, Wang and Kurzman (2007) found that brokers are well-organised, have some political knowledge, and clear division of labour. Stokes et al. (2013), meanwhile, defined brokers as intermediary actors living or active in a target area, with such close spatial relations between brokers and voters being paramount to their success. Brokers occupy an important and strategic position, as they are capable of understanding the real conditions faced by communities. In an Indonesian context, a comprehensive study by Aspinall and Sukmajati (2015) finds that, conceptually, campaign teams are the most common channels for brokerage-even though formal and informal social networks, as well as political parties, are also present. Based on the above definitions, political brokers can be understood in the context of this article as formal agents that live within a specific area and understand the socio-political conditions of a community, thereby enabling them to mobilise political support for their candidates.

If these two key concepts are combined, this article positions the PKK in Batu as a corporatist state agency-cum-political broker, being characterised by formal networks, close physical proximity to communities, and an understanding of the socio-political conditions in said communities. Findings in the field indicate that the PKK has been mobilised to gather political support. In short, this article 
shows that some PKK cadres have become involved in another form of political brokerage, namely campaign teams. Nonetheless, this article focuses on PKK networks. Also interesting is that, rather than become a neutral corporatist social organisation as hoped, the PKK was used to gather political support for incumbents in the Batu municipal election.

Methodologically, the data for this research was collected through in-depth interviews, participatory observations, and shadowing in January and February 2017. This article is divided into five sections. The first is the introduction, which presents a review of the literature about political brokerage in elections and theoretical considerations of corporatist state institutions and clientelism in Indonesian democracy. The second section presents an overview of the research location, profiles the candidates who contested the 2017 municipal election in Batu, and the general dynamics of PKK in Batu. The third section seeks to explain factors that allowed the pair of Dewanti Rumpoko-Punjul Santoso to exploit PKK networks to mobilise support. The fourth section examines how PKK cadres sought to mobilise voters despite formal regulations that required them to remain neutral in elections and campaigns. The fifth section presents the findings of the research and data analysis.

\section{Batu in Context: The Municipal Election and PKK}

This section is divided into two sub-sections, to better understand the socio-political context of Batu. The first sub-section will map the contestations between candidates in the 2017 Batu municipal elections. The second sub-section will explore the general conditions of the PKK of Batu, including its organisational structure, activities, and core duties. This introduction is intended to provide a basic understanding of this corporatist state organisation and its role in empowering communities - particular women. Furthermore, this introduction is hoped to help guide the understanding of how PKK was mobilised by Dewanti Rumpoko developed through subsequent sections. 
Batu was the only one of the 38 regencies and municipalities in East Java to hold its elections during the simultaneous elections of 2017. After becoming a new autonomous region, independent of Malang, in 2001, Batu has held three direct regional elections: in 2007, 2012, and 2017. The first mayor of Batu, H.M. Imam Kabul, was appointed to office legislative in 2001, before Indonesia introduced its direct election policies. The first two regional elections held in Batu, in 2007 and 2012, were won by Eddy Rumpoko, who served as mayor for two successive periods.

In his first term, Eddy Rumpoko was paired with Boediono, while in his second term his deputy was Punjul Santoso. In both elections, Eddy Rumpoko was nominated by the Partai Demokrasi Indonesia Perjuangan (Indonesian Democratic Party of Struggle; PDIP). In the 2017 election, Dewanti Ruparin Dyah—better known as Dewanti Rumpoko, the wife of Eddy Rumpoko-was elected to serve from 2017 to 2022, with her deputy being the incumbent Punjul Santoso.

Under two terms of Eddy Rumpoko's leadership, Batu experienced rapid growth (Aminudin, 2015). Research from the University of Jember indicates that economic growth in Batu during the mayor's first term (2007-2012) increased from 6.8\% to $8.04 \%$ (Zaenurullah, Boedijono, \& Suryawati, 2015). Meanwhile, in Eddy Rumpoko's second term, economic growth in Batu remained at $8.03 \%$, higher than the average in East Java (5.9\%) and nationally (5.1\%) (Sofi'I, 2015). Tourism and agriculture were identified as the region's most rapidly growing sectors, and were thought to have a positive and direct effect on the local economy. Batu has considerable potential in both sectors. Owing to its location in the highlands, the city is temperate, and it is thus an ideal destination for tourism and agriculture activities (Kota Batu dalam Angka, 2015).

The 2017 Batu Municipal Election and the Victory of Dewanti Rumpoko The 2017 Batu municipal election was contested by four 
candidates and their deputies, who sought the support of some 149,728 registered voters. One candidate was Dewanti Rumpoko, the wife of the incumbent mayor Eddy Rumpoko, who ran together with Punjul Santoso, the incumbent deputy mayor. These candidates, who were listed second on ballots, were nominated by PDIP. The other candidates and their running mates were: RudiSujono (ballot number one, nominated by Partai Amanat Nasional [National Mandate Party, PAN], Partai Nasional Demokrat [National Democratic Party, Nasdem], and Partai Hati Nurani Rakyat [People's Conscience Party, Hanura]); Hairuddin-Hendra Angga Sonata (ballot number three, nominated by the Partai Kebangkitan Bangsa [National Awakening Party, PKB] and Partai Demokrat [Democratic Party]); and Abdul Madjid-HA. Kasmuri Idris (ballot number four, independent).

Table 1.1

Mayoral and Deputy Mayoral Candidates in Batu, 2017-2022

\begin{tabular}{|c|c|c|c|c|}
\hline & Candidate I & Candidate II & Candidate III & Candidate IV \\
\hline $\begin{array}{c}\text { Candi- } \\
\text { dates' } \\
\text { Names }\end{array}$ & $\begin{array}{c}\text { Rudi- } \\
\text { Sujono }\end{array}$ & $\begin{array}{c}\text { Dewanti Rumpo- } \\
\text { ko -Punjul } \\
\text { Santoso }\end{array}$ & $\begin{array}{c}\text { Hairuddin - } \\
\text { Hendra Angga } \\
\text { Sonata }\end{array}$ & $\begin{array}{c}\text { Abdul Madjid - } \\
\text { HA. Kasmuri Idris }\end{array}$ \\
\hline $\begin{array}{c}\text { Backing } \\
\text { Party }\end{array}$ & $\begin{array}{c}\text { PAN, } \\
\text { NASDEM, } \\
\text { HANURA }\end{array}$ & PDIP & $\begin{array}{c}\text { PKB, } \\
\text { DEMOKRAT }\end{array}$ & INDEPENDENT \\
\hline
\end{tabular}

Source: General Elections Commission of Batu

Based on this mapping of candidates in the Batu municipal elections, it is clear that candidates had diverse models and support bases. The first candidate, Rudi, and his running mate Sujono, respectively had backgrounds in agriculture and art. Their greatest asset in the election was their status as "Sons of the Region" (i.e. having been born and raised in Batu).

Dewanti and Punjul, meanwhile, inexorably relied on their incumbency. Dewanti is the wife of Eddy Rumpoko, who served two terms as mayor, while at the time of the election Punjul Santoso 
had already spent one term as deputy mayor of Batu. This factor offered the candidates significant capital, as the government under Eddy Rumpoko and Punjul Santoso was widely perceived to have successfully promoted the development of Batu.

The candidates who were third on the ballot, Hairuddin and Hendra, attempted to represent themselves as representatives of the Nahdliyin santri (orthodox Muslims). These candidates had strong ties both with a Muslim party (Hairuddin, often known as Gus Din, is a senior figure in the Islamic party $\mathrm{PKB}$ ) and nationalist party (Demokrat). The final pair of candidates, A. Madjid and Kasmuri Idris, were independent, not nominated by any parties. However, they had previous electoral experience, having come in second in the 2012 elections behind Eddy Rumpoko.

With her 2017 electoral campaign, Dewanti Rumpoko became the first woman to run for mayor of Batu. Data released by the elections commission of Batu indicates that Dewanti Rumpoko and Punjul Santoso were nominated only by one party, PDIP, in which they were members. After time, they were able to gather the support of several other political parties, including the Partai Golongan Karya (Functional Groups Party, Golkar), Partai Gerakan Indonesia Raya (Great Indonesia Movement Party, Gerindra), Hanura, and Partai Keadilan Sejahtera (Prosperous Justice Party, PKS. However, these parties remained supporting parties, rather than nominating parties. According to Dewanti Rumpoko, this is because PDIP held $20 \%$ of seats in the regional parliament (i.e. 5 of 25 total seats); pursuant to Indonesian elections law's, ${ }^{4}$ the party could thus nominate its own party without collaborating with any other party. As such, administratively the parties that later backed Dewanti Rumpoko and Punjul Santoso were classified as mere supporting parties.

Various negative issues "unique" to the Batu municipal elections emerged, many of which were targeted at Dewanti, a

4 Regulation of the General Elections Commission No. 9 of 2016 regarding the Candidacies and Elections of Governors and Deputy Governors, Regents and Deputy Regents, and/or Mayors and Deputy Mayors. 
fact that was strongly linked to her status as the wife of two-term incumbent Eddy Rumpoko. Over the course of her campaign, Dewanti was targeted by rumours that she was creating a political dynasty, in which regional leadership would remain under a single family. One private television station, Metro TV, invited Dewanti and Eddy to speak during a special broadcast on political dynasties and the 2017 regional elections, one month before the elections. During this broadcast, Dewanti not only argued in support of her own candidacy to replace her husband as mayor, but also countered claims that she could potentially abuse the power of the incumbentsuch as by exploiting PKK networks in gathering support.

However, this had little effect on Dewanti Rumpoko's electability. One local research institution in Malang, hired by a PDIP's competitor to investigate the prospects for nominating mayoral and deputy mayoral candidates, found that Dewanti Rumpoko had greater popularity, electability, and acceptability than other potential candidates in the pre-nomination phase. ${ }^{5}$ This research institution also found a contradiction in preferences for candidates expected to contest the 2017 Batu municipal election. In general, the people of Batu rejected the practice of dynasty politics, but considered Dewanti Rumpoko's candidacy to be acceptable. Several researchers and observers of local politics argued that Dewanti Rumpoko enjoyed a high level of popularity and electability because she was close to grassroots communities through her involvement in their activities (Krisnohadi, interview, January 9, 2017; Romadoan, interview, January 9, 2017). ${ }^{6}$ Her ability to guide social organisations such as PKK was positively received by the public.

Following the election, held on 15 February 2017, the

The name of the research institution and political party, as well as the detailed results of the research, cannot be stated explicitly, owing to the contract between the research institution and political party.

6 Drs. Krisnohadi, MA (Lecturer at the Government Sciences Department, Universitas Muhammadiyah Malang); Ruli Inayah Romadoan, Msi (Lecturer at the International Relations Department, Universitas Muhammadiyah Malang). 
elections commission announced that Dewanti Rumpoko and her running mate Punjul Santoso had won the election, receiving 51,748 votes ( $44.46 \%$ ), followed by Rudi-Sujono with 24,228 votes (20.82\%), Hairuddin-Hendra AS with 20,507 votes (17.62\%), and Abdul Madjid-Kasmuri Idris with 19,897 votes (17.10\%). Dewanti and Punjul won every district in Batu with at least $40 \%$ of the votes.

\section{The PKK in Batu}

In examining the electoral victory of Dewanti Rumpoko and Punjul Santoso, the role of the PKK - in which Dewanti was active for the ten years of her husband's mayoral term-cannot be ignored. PKK is an organisation for women established to work in coordination with the government. Soetjipto and Adelina (2013) identify this organisation as being integrally linked with the bureaucracy, as it is always led by the wives of government officials. At the national level, the PKK is headed by the wife of the Minister of Domestic Affairs, and in the provincial, regency/municipality, and village level it is headed by the wives of officials. PKK is found throughout Indonesia, where it occupies a strategic position and role owing to its ability to reach people at the grassroots level. PKK has ten key programmes to guide it in its activities, and is expected to work together with regional governments at the regency/municipal level.

Batu, as with other parts of Indonesia, has PKK branches from the municipal to the dasa wisma (the smallest unit in the PKK network, consisting of ten households) level, and has generally been led by the wives of local officials. As the wife of the two-term incumbent mayor, Dewanti Rumpoko automatically became responsible for the PKK in Batu and its activities. Regarding the activity of PKK cadres in programmes and activities at the grassroots level, Soetjipto and Adelina (2013) argue that the automatic positioning of regional leaders' wives as the heads of regional/municipal PKK groups often ignores such women's lack of management capacity, and this has 
implications for the activities of PKK groups down to the grassroots level. Nonetheless, observing the active performance of PKK in Batu and its numerous programmes, it may be concluded that the organisation, under the leadership of Dewanti Rumpoko, served as an effective strategic partner for the government.

From interviews conducted with PKK cadres in three districts in Batu, it may be concluded that, under the leadership of Dewanti Rumpoko, the ten key PKK programmes were not mere slogans, but actualised through concrete action. This includes, for example, the long-term Keluarga Harapan ('Family of Hope', PKH) programme, intended to address poverty and improve education, was manifested through training programmes, financial aid to women seeking to establish home industries, and scholarships for poor children (informant, interview, February 20, 2017). ${ }^{7}$

Furthermore, in Batu the PKK positioned itself as an active actor seeking to articulate the needs of local communities, particularly those of women, rather than simply facilitate government programmes. To facilitate its efforts, the PKK held monthly meetings with its district-level cadres, which was intended to give them direction and monitor their programmes. After each meeting, the district-level PKK cadres would meet with those under them and share the results of their discussions; these meetings were also held monthly. Aside from this, in actualising their activities, PKK cadres acted creatively and utilised available opportunities to work with the private sector. For example, in Mojorejo District, the PKK worked together with Tupperware, Wings Food, and Toyota for its social activities (informant, interview, January 21, 2017). ${ }^{8}$

Interview with a PKK cadre in Sanggrahan Village.

Interview with the head of PKK in Mojorejo District. 


\section{The Return of Corporatist State Organisations in Regional Elections}

In contesting the 2017 Batu municipal election, Dewanti Rumpoko involved PKK cadres in her campaigning and voter mobilisation. This is not unexpected given her ten years as the leader of the PKK in Batu, as well as her resulting popularity. This also indicates, however, that corporatist state organisations (PKK) have again become involved in elections in the current democratic era, a characteristic that had marked them in the authoritarian New Order era. From field research conducted during the campaign, up to and including the election, it is apparent that several factors made it possible for the PKK to again become involved in election campaigns: its organisational structure and hierarchy, and the clientelism found within the organisation. Both of these factors are closely related, and in combination they were capable of reviving the practice of mobilising votes through corporatist state organisations. Owing to this phenomenon, the ideal prediction of MacIntyre (1994) will be difficult to realise.

\section{Organisational Structure and Processes of PKK}

The first discussion focuses on the organisational structure of and processes used by PKK. Indonesian Institute of the Sciences researcher Syarfina Mahya Nadila has optimistically argued that, after the end of the New Order, the PKK was no longer considered a relevant means of ideological control (Akmaliyah, 2014). However, this view is belied by the results of field research in Batu, which indicate that the organisation is still relevant as a means of ideological state control, or at least gathering political support. Two main points support this argument: first, the highly hierarchy structure of PKK down to the household level, and second, the top-down conveying of instructions. These were compounded by the fact that, for two terms, leadership of the organisation in Batu was handled by Dewanti Rumpoko, who ran for mayor in the 2017 municipal election. 
According to interviews with one PKK cadre in Bumiaji District (January 30, 2017), every month the municipal-level PKK office held meetings with PKK cadres from the district level, after which district-level PKK branches would hold meetings with PKK cadres from the village/sub-district level, and again down to the dasa wisma level. This hierarchy structure of meetings was intended to improve that the socialisation and evaluation of programmes is wellhandled, from the highest level to the lowest level. In this structure, in which instructions are conveyed in a top-down manner, various activities - including political campaigning-become easier. This is reflected in the research findings.

Approximately one month before the 2017 municipal election, the municipal PKK office became more actively involved with village and district offices and their meetings. This was stated to be part of the organisation's efforts to record the hopes and aspirations of communities and to evaluate the PKK's top-down programmes. During non-campaign periods, such activities are uncommon. One PKK cadre from Bumiaji District stated that, during a meeting in Tulungrejo Village, Dewanti Rumpoko introduced herself as candidate number two and asked attendees for their prayers and blessings as she campaigned for mayor of Batu. She also had attendees yell out her campaign slogan, Salam dua jari! ('Two finger salute!'), and hold their fingers in the shape of a V.

One PKK cadre from Tulungrejo, although careful with her answers, openly admitted that she had received instructions from Dewanti Rumpoko to socialise her slogan and the two-finger salute among other cadres, and to use it in every PKK activity.

"It's like this. The PKK was handled by Bu Dewanti, and so whatever she recommended, we would say "Two finger salute!" (makes a V or peace sign with fingers). So we'd say this (at PKK events) But voting, that's the right of every citizen. We would just use the greeting." (Informant, interview, January 31, 2017). ${ }^{9}$

Interview with a PKK cadre in Tulungrejo Village.

Original: Jadi begini, PKK dipegang oleh Bu Dewanti, sehingga apa yang disarankan $\mathrm{Bu}$ Dewanti, ya (penggunaan-pen.) salam dua jari (sembari memeragakan jari membentuk 
Furthermore, in Pendem, the sub-district chief's wife-the leader of the local PKK branch-instructed one cadre to tidy the front yard of the early childhood education centre where Dewanti would speak about wearing the hijab (while simultaneously campaigning). Although this cadre was concerned at first about this instruction, keeping in mind that her daughter was part of the village administration and that her early childhood education centre was being used for political campaigning, the wife of the sub-district chief assured her that following this instruction and supporting this activity would not negatively affect her.

If abstracted, it may be argued that the PKK's hierarchy structure, from the municipal level to the village level, allowed this corporatist state organisation to become an important means of mobilising voters. This hierarchy structure is needed for PKK to coordinate its instructions down to the dasa wisma level and to conduct routine programmes. The hierarchy for such programme coordination was, in the municipal election, transformed into a means of communicating a candidate's instructions to cadres and thereby collecting political support for that candidate. Furthermore, owing to the minimal opportunities available for PKK members to argue against or even reject instructions from those higher in the hierarchy, the candidate-who occupied the highest office in the municipal PKK — was free to mobilise cadres for her campaign and to gather cadres to promote her own interests. Furthermore, the cadres required the support of those above them to ensure the security of their own positions, given that-as members of a corporatist state organisation - cadres and administrators may not become involved in political activities. The following scheme illustrates the flow of instructions within the structure of the PKK. 
Fig 1. Hierarchy Structure and Flow of Instructions within the PKK of Batu Municipality

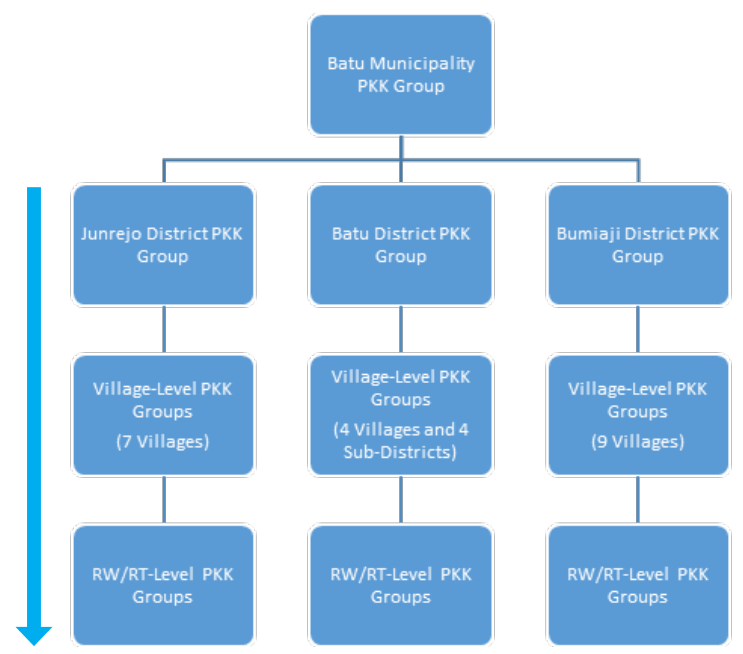

Note: Top-down dissemination of instructions

\section{Clientelism}

The second factor is the clientelism within the PKK. Theoretically, clientelism is defined by Hicken (as cited in Aspinall \& Sukmajati, 2015) as direct and personalistic relations between clients and patrons (i.e. politicians), with three core aspects: an exchange of material resources for votes, uneven power between patrons and clients (hierarchy), and repetition (i.e. continuous exchange). Meanwhile, another theory defines (second-wave) clientelism as the exchange of loyalty and votes for resources such as employment opportunities, contracts, and access to services (Roniger, 2004).

According to field research, cadres - the informants - stated that the leadership of Dewanti Rumpoko helped them facilitate and initiate various PKK programmes, and thus enabled them to assert their own existence as PKK members. As one informant stated in an interview, the PKK in Batu plays an important role within the municipal government, as it has accurate information on residents 
and communities down to the dasa wisma level. This is inexorably linked to its successful programmes in local communities. For example, the Posyandu (integrated service posts), in which PKK plays an important role, have numerous derivative programmes, including Bina Keluarga Balita (Guidance for Families with Infants), pre-early childhood education, and the Forum Anak dan Remaja (Children and Teenagers' Forum). Meanwhile, PKK members can be better recognised, unlike in previous eras, when members were only rarely considered by their communities (informant, interview, February 1, 2017). ${ }^{10}$

Under Dewanti's leadership, PKK members gained more opportunities to become involved in various activities, from the village to the provincial level. One cadre active at the sub-district level stated that, before Dewanti assumed leadership, PKK was often ignored and considered unimportant by outsiders (informant, interview, February 21, 2017). ${ }^{11}$ Under Dewanti, however, members of the organisation were urged to actively participate in various community activities, such as village development planning meetings. Members were also expected to participate in various competitions, such as singing contests, and some won prizes. This was effective in showing the public that PKK members were proud of their work and contributions to society (informant, interview, February 21, 2017). ${ }^{12}$ Similar experiences were voiced by a cadre from Junrejo.

"So if there are any activities, with the women, it will succeed... because PKK, its activities are real, and they can reach out and embrace the men. For example, in PKK there's the dasa wisma. Collecting data at the household, then the neighbourhood level, it's most accurate through the dasa wisma. The district chief asked, "How many are pregnant here?", he asked the PKK. See, all aspects of life are there at $P K K$. With us making all these activities happen, it's as if everyone supports the PKK." (Informant, interview, February 21, 2017). ${ }^{13}$

10 Interview with a PKK cadre in Bumiaji District.

11 Interview with a PKK cadre in Beji Sub-District.

12 Ibid.

13 Original: Jadi kalau ada kegiatan yang mengarahkan perempuan itu pasti sukses. . Karena PKK itu kegiatannya nyata. Terus bisa merangkul bapak-bapaknya. Misalnya, di PKK itu ada 
The rise of such social activities under Dewanti's leadership was also seen as an opportunity for PKK members to express themselves. As stated by one PKK secretary at the district level, "See, the PKK worked closely together. Went about here, there, and that made people interested in coming. The important thing was coming, being themselves. Turned out that Ibu Wali (i.e. Dewanti) liked this too." (informant, interview, January 30, 2017) ${ }^{14}$ Furthermore, cadres at the lower levels of the PKK structure found a sense of pride in meeting with and being known by Dewanti. This was most possible during PKK meetings and activities, as stated by one senior member:

'Bu Wali didn't know I'm a soldier's wife. She was curious... 'Every time there's an activity, there's that woman'. Before, just a few years ago, only after she got information about me, did she know. 'You're a soldier's wife? No wonder you're so (active with the PKK, ed.). If only I'd known before." (Informant, interview, February 1, 2017) $)^{15}$

Furthermore, material incentives such as free milk, financial support (such as for transportation), and health insurance were given to, cadres as they participated in PKK activities. This is unlike the findings of Soetjipto and Adelina (2013), who describe PKK members as working without any payment.

"In Batu, cadres receive an incentive, even if it's just $R p$ 50,000.00 per month. We're very grateful to have so many facilities. In Pak Eddy Rumpoko's first term, Bu Dewanti gave insurance to all the cadres, health insurance... of course there are

dasa wisma. Mulai mendata KK (Kartu Keluarga-pen), terus sampai RT-RW itu, paling akurat dasa wisma. Bapak camat itu sampai tanya, «Itu yang hamil berapa di situ?», itu tanya PKK. Soalnya semua aspek kehidupan itu ada di PKK. Dengan kami wujudkan semua kegiatan itu, justru kelihatan semua mendukung PKK.

14 Interview with a PKK cadre in Bumiaji District.

Original: Nah, di sini PKK itu kompak, eksis. Gaya-gaya di sini, itu yang membuat mereka tertarik datang. Yang penting tampil, pokoknya aku. Nah kebetulan ibu wali (Dewanti-pen) juga gaul, eksis

15 Interview with a PKK cadre in Giripurno Village.

Original: Bu wali itu tidak tahu saya istri tentara. Dia cuma penasaran, 'Saya setiap ada kegiatan pasti ada ibu itu'. Dulu Cuma, beberapa tahun yang lalu ya, begitu ada informasi tentang saya, aakhirnya baru tahu. 'Lho jeng, njenengan ini istri tentara ya, pantas begitubegitu (aktif kegiatan PKK-pen). Coba saya tahu dari dulu ya. 
operational costs. For transportation, the women, if there are activities some where, there is money for their transportation. So, maybe the women get only a little, but even though it's little (in amount, ed.) there's something to help them. I think it depends on the leader, how she reaches out to the women". (Informant, interview, February 21, 2017) ${ }^{16}$

It is known, that, pursuant to mayoral decree, since 2012 the government of Batu has provided Rp1,000,000,000.00 in grants to cover PKK's operational costs. ${ }^{17}$ In 2015 , the Batu government again allocated financial assistance to the PKK, providing members with up to Rp75,000.00 in compensation for every official trip made within the Greater Malang region. ${ }^{18}$ Although this nominal amount was not particularly large, it was sufficient to ensure that the PKK cadres felt their activities were being recognised by the government. As such, when Dewanti ran for mayor of Batu, some PKK cadres sought to repay her by supporting her campaign.

Meanwhile, in Junrejo Village, one PKK cadre (interview, February 17, 2017) who also headed the organisation's kindergarten expressed concern for the continued supply of milk to her school. She felt that, with a new mayor (and, thus, new policies), her school could possibly stop receiving such assistance, which was intended to ensure proper nutrition among kindergarten and elementary school students and given every Friday. The informant also expressed interest in the announcement that batik uniforms would be freely provided to kindergarten students should Dewanti be elected mayor. ${ }^{19}$ As these promises and incentives would not be possible if another candidate were to be elected, the informant decided to

16 Interview with a PKK cadre in Junrejo District.

Original: Di Kota Batu, kader itu ada insentifnya. Biarpun cuma Rp50.000,00 saja per bulan. Kita bersyukurlah fasilitas itu banyak sekali. Periode pertama Pak Edy Rumpoko, $\mathrm{Bu}$ Dewanti mengasuransikan semua kadernya, asuransi kesehatan...Tentu ada BOP, biaya operasionalnya. Jadi untuk transportnya ibu-ibu, kalau misalkan acara ke mana itu ada transport. Jadi dari situlah mungkin ibu-ibu sedikit, walaupun [nominalnya -ed.] sedikit tapi diberikan bekal. Saya kira itu tergantung ketuanya ya, untuk merangkul ibuibu.

17 Regulation of the Mayor of Batu Nomor 5 of 2012 regarding the Provision of Grants to the Family Welfare Guidance Programme of Batu.

18 Decree of the Mayor of Batu No. 188.45/51/KEP/422.012/2015.

19 Interview with the Head of the PKK of Junrejo Village. 
support Dewanti Rumpoko. Similar concerns were expressed by one village-level PKK cadre (interview, February 20, 2017), who felt her concerns sufficient reason to support Dewanti,

"So because she (Dewanti, ed.) understands the political conditions, and the social issues, she knows them too. It's different than if, for example, there were a new mayor. Maybe, in the new term, if he (the new mayor, ed.) were from outside Batu, maybe he would make new programmes. That might be troublesome. But Bu Dewanti, she just needs to continue (her programmes, ed.)". ${ }^{20}$

These findings indicate the existence of clientelism within the organisational structure of PKK. PKK cadres, as clients, require channels and material support to express their organisational and personal existence. Dewanti Rumpoko, meanwhile, positioned herself as a patron capable of both leading the PKK organisation as well as fulfilling PKK cadres needs through her programmes. Cadres' need for channels pushed them to become actively involved in different social activities, as well as various contests and competitions. Meanwhile, their need for access to material resources-i.e. financial incentives and other supplies-was met through the provision of financial compensation to cadres and free milk to educational institutions, including schools operated by PKK cadres. Because of these programmes, PKK cadres felt as though was capable of fulfilling their needs. In return for this support, and to express their own expectation that such needs fulfilment would continue, PKK cadres gave their political support to Dewanti.

\section{An Old Organisation in a New Political Climate}

Changing political contexts have, of course, demanded that PKK adapt its organisational strategies and approaches to mobilise political support for candidates. By comparison, in the

20 Interview with the Head of the PKK of Sanggrahan Village.

Original: Jadi karena dia ini paham kondisi politiknya. Kemudian isu sosialnya juga tahu. Lain lagi kalau misalkan walikotanya baru. Mungkin kalau periodenya baru, kemudian dia dari luar Batu, beliaunya mungkin akan membuat program baru. Itu mungkin akan kesulitan. Tapi kalau Bu Dewanti tinggal meneruskan saja. 
New Order era, members of corporatist state organisation-such as PKK-would explicitly and publically state their support for the government. At massive events held in open places such as stadiums, civil servants, PKK cadres, and Dharma Wanita members were mobilised by the government in a top-down manner to support the ruling party, Golkar, in its campaigning. During such events, they were expected to wear their uniforms as they interacted with state bureaucrats and other corporatist state organisation members. At the time, this was not seen as a violation of campaign ethics (Soebhan, 2000).

After the end of the New Order, according to Minister of Domestic Affairs Gamawan Fauzi, the PKK was urged to remain neutral in politics, particularly during elections. This also influenced the PKK of Batu in supporting Dewanti, as the explicit and open approaches used in the past were no longer tenable. Furthermore, owing to the organisation's structure, most of those in charge at the district level were civil servants who were likewise expected to remain neutral. As such, research has found that various means were used to support Dewanti, starting from posting pictures with her while giving the two-finger salute on WhatsApp, and expanding to direct support of the candidate and her campaign. These were, however, hidden by the cadres and campaign teams from the mass media, (Malik, interview, January 9, 2017) ${ }^{21}$ general elections commission, (Mahyuni, interview, January 17, 2017) ${ }^{22}$ and elections monitoring committee.

This was experienced, for example, by one cadre at the district level (interview, February 21, 2017), who took the initiative to facilitate a meet and greet between Dewanti and PKK cadres. The informant consciously recognised that this meeting was the easiest way of collecting political support and having Dewanti meet with her constituents. To avoid any possible consequences from

\footnotetext{
21 Malik, CNN contributor, East Java Bureau.

22 Mahyuni, a member of the General Elections Commission for Batu Municipality. It was
} 
the general elections commission, owing to its lack of neutrality, the informant invited the three other candidates to Junrejo district. However, by the end of the event, none of Dewanti's competitors had come (interview, February 21, 2017). ${ }^{23}$

Another, more passive means of support, involved the facilitation of political excursions to Junrejo in the evening, when potential coverage was minimal, or to Pendem on Sundays when most women were at home. Following the instructions of the sub-district chief's wife, the secretary of the Junrejo PKK-and a respected community figure-had no difficulty collecting 100 women to attend a meeting in which they could express their aspirations and receive free hijabs valued at Rp10,000.00 each. A similar case in Pendem was handled by the local PKK leader and cadres. To avoid suspicion, the PKK team functioned primarily as "vendors", offering the yard of the early childhood education centre for Dewanti's hijab and make-up training session.

"To be honest, I simply want the knowledge I gain from these activities. I just offer a place in the yard of the early childhood education centre (which is located on the front patio of the informant's home, ed.), and the contents of the activity are prepared by her team." (Interview, February 5, 2017) ${ }^{24}$

When Dewanti held a campaign event in a stadium, the experiences of the PKK cadres from Bulukerto were interesting. For this event, each village-level PKK leader was expected to bring fifty women from the prayer groups being guided by the PKK. According to one informant, this meant that the PKK leaders of 24 villages throughout Batu were expected to bring a total of 1,200 people. One of the greatest challenges was mobilising the women and ensuring that they participated enthusiastically. Given that they

recognised that candidates frequently changed the locations and times of their campaign events.

23 Interview with a PKK cadre in Junrejo District.

24 Interview with a PKK cadre in Pendem Village.

Original: Saya jujur hanya ingin mendapat ilmunya dari kegiatan ini. Cuma menyediakan tempat saja di halaman PAUD, untuk isi acara sudah ada timnya ibu yang mengatur. 
were mostly farmers who earned a living through hard labour in the fields, taking a day off for the campaign would mean not being able to work for that day. In exchange, the PKK cadres were informed that Dewanti's campaign team would distribute Rp50,000.00 to Rp100,000.00 in sangu money (i.e. money for petrol) to women who were willing to participate in group prayers at the Youths and Sports Office, which was located near the stadium. This money served not only to cover attendees' transportation costs, but also remunerate them for their lost income. PKK cadres also promised a free lunch to all participants.

"For Bu Dewanti, we were asked to collect the women from the prayer groups for events, such as the reog dance, the sandukan dance. During the prayer groups' meetings they were gathered.... Before the campaigning, there would be prayers first. So from the village, the PKK, we were asked to bring members. That was fifty from each village, from the women of the PKK... We facilitated those 50 women with five cars from the village. There, they gave us money for petrol. ... Yes, because without (this money), it would be a pity. We'd be burdened." (Interview, February $5,2017)^{25}$

Although this event clearly favoured Dewanti, to promote the perception of neutrality, the PKK welcomed other candidates who visited Bulukerto and reported every activity to the balloting committee. Another important consideration was residents' sense of discomfort, given that Bulukerto was the home village of another candidate, Rudi. Although PKK acted as its own political broker, members in reality required the support of Dewanti's campaign team and the party backing her.

Content of both indoor campaign activities, such as the hijab tutorials in Pendem and Junrejo, and outdoor campaign activities,

25 Interview with a PKK cadre in Bulukerto Village.

Original: Untuk $\mathrm{Bu}$ Dewanti kemarin kita diminta mengumpulkan ibu-ibu pengajian untuk ikut acara apa itu, acara seni reog, sandukan (tarian tradisional-pen.). Sama waktu pengajian itu juga dikumpulkan...Sebelum kampanye itu ada ngaji-ngaji dulu. Jadi dari desa dan PKK itu kita disuruh mendatangkan anggota jamaah-jamaah. Itu masingmasing desa 50 orang, itu dari ibu-ibu PKKnya saja...Kita fasilitasi 50 orang itu pakai 5 mobil-mobil dari desa, nanti di sana diganti uang bensin... Iya karena (tanpa uang bensinpen.) kasihan juga, kita yang beban. 
such as that at Brantas Stadium, was managed entirely by the TwoFinger Action volunteer team. Because members of this team were not bound to be neutral by ethics considerations, they could more readily campaign openly. The following statement, by a former leader of the Family Planning team, secretary for the local PDIP branch, and member of the Two-Finger Action team, illustrates how corporatist state organisations such as PKK worked with volunteer teams.

"... It happens that PDIP nominated Ibu Dewanti... We mobilised all of the women, the women's groups, in all sorts of organisations in Batu, said, 'Come on, let's support Ibu Dewanti'. ... That included empowerment among the women at $P K K$, to make sure they have an income." (Interview, January 21, 2017) ${ }^{26}$

This quotation also indicates that women's issues were a major factor in developing strategic relations between PKK and the campaign team in their support of Dewanti, including the division of labour. Furthermore, this informant is a former PKK administrator who held an important position, and thus was able to exploit connections within the structure of the corporatist state organisation. It is because of relations such as these that the PKK enabled Dewanti's campaign team to collect information on villages (informant, interview, January 30, 2017). ${ }^{27}$ Meanwhile, the PKK cadres and activists found an opportunity to avoid violating the neutrality recommended of all corporatist state organisations by the Minister of Domestic Affairs: although the organisation could not support a particular candidate or party in election, individuals retained their right to promote their own political views.

The research argues that this opportunity was exploited by cadres to become actively involved in, rather than separately

26 Interview with a former PKK cadre and Aksi Dua Jari volunteer, Batu District.

Original: Kebetulan PDIP itu mencalonkan Ibu Dewanti...Kami menggerakan semua perempuan-perempuan, elemen perempuan, di berbagai macam organisasi di Batu, bahwasanya ayo kita mendukung Ibu Dewanti...Termasuk pemberdayaan ibu PKK, jangan sampai perempuan ini di rumah tidak punya penghasilan.

27 Interview with a PKK cadre in Bumiaji District. 
coordinate with, the volunteer team. Although it was not stated explicitly, from statements such as that of the PKK secretary of Bumiaji district it is clear that in several cases cadres overstepped the boundaries by joining Dewanti's campaign team (informant, interview, January 30,2017$).{ }^{28}$ The validity of this information was confirmed by an informant in Mojorejo, a village located near Batu Kota district: "(Joining the campaign team, ed.) was automatic (for PKK cadres in the central district branch, ed.). Even if it wasn't too blatant, it was understood" (interview, February 21, 2017). ${ }^{29}$ This statement indicates that PKK cadres holding dual roles, particularly in the central district (kota) branch, was considered acceptable and normal. Cadres did not problematise the status of others, and often concealed information regarding their involvement from outsiders, including the researcher.

\section{Conclusion}

The case of Batu indicates that, in the current democratic era, corporatist state organisations remain relevant as political brokers during elections. Several factors made the PKK an important means of mobilising support for Dewanti Rumpoko, including the highly hierarchy organisational structure, top-down operational approach, and clientelistic relationships within the organisation. Compared to her three opponents, Dewanti, as the (wife of) the incumbent mayor, enjoyed an incumbency advantage in her exploitation of these factors, and field research indicates that she was capable of optimally activating PKK for her campaign.

Furthermore, despite ideally being neutral in elections owing to its position as a corporatist state organisation, the PKK was used by its cadres to mobilise support through various means. Members' activities ranged from personal efforts such as posting pictures of

28 Ibid.

29 Interview with a PKK cadre in Mojorejo Village.

Original: Otomatis kalau itu, meskipun tidak terlalu apa ya, nampak. Tapi kan kita sudah paham. 
them with Dewanti on the application WhatsApp to providing campaign venues and even actively joining the Two Finger Action Team. Owing to this support and these strategies, PKK was an important means for Dewanti Rumpoko to mobilise support during the 2017 municipal election in Batu. Building on this research, it is possible to explore how other extant corporatist state organisations first established in the New Order, such as Karang Taruna and Dharma Wanita, may potentially be exploited by candidates to gather political support in elections. Of course, the relevance of this potential requires further consideration through subsequent studies. 


\section{References}

UU Nomor 8 Tahun 1995 tentang Organisasi Kemasyarakatan [E-Reader Version]. (2010). Retrieved from http://konsillsm.or.id/uu-no-8tahun-1985-2.

Peraturan Wali Kota Batu Nomor 5 Tahun 2012 tentang Pemberian Hibah Kepada Pemberdayaan Kesejahteraan Keluarga Kota Batu [E-Reader Version]. (2012). Retrieved from http://kotabatu. jdih.jatimprov.go.id/download/Peraturan\%20Walikota/ PERWALI\%202012/5.PERWALI\%20HIBAH\%20PKK\%20 2012.pdf.

Kota Batu dalam Angka, Batu City in Figures 2015 [E-Reader Version]. (2015) Retrieved from BPS Kota Batu Website: https://batukota. bps.go.id/website/pdf.../Statistika-Daerah-Kota-Batu-2015.pdf.

Keputusan Wali Kota Batu Nomor 188.45/51/KEP/422.012/2015

[E-Reader Version]. (2015) Retrieved from http://kotabatu. jdih.jatimprov.go.id/download/Keputusan\%20Walikota/ kepwali_2015/51.\%20PERJ.\%20DINAS\%20PKK\%202015.pdf.

Akmaliyah, W. (2014). Menimbang urgensi PKK pasca Orde Baru. Retrieved from LIPI Website:

http://pmb.lipi.go.id/menimbang-urgensi-pkk-pasca-orde-baru/.

Aminudin, M. (2015, 5 November). Cerita di balik Wali Kota Batu yang berani kembalikan dana desa. Detik Finance. Retrieved from https://finance.detik.com/.

Aspinall, E., \& Sukmajati, M. (2015). Politik uang di Indonesia: Patronase dan klientelisme pada pemilu legislatif 2014. Yogyakarta: Penerbit PolGov.

Burhanudin, J., \& Fathurahman, O. (2004). Tentang perempuan Islam: Wacana dan gerakan. Jakarta, Indonesia: Gramedia Pustaka Utama.

Carrasco, G. (1993). Democracy's interest in groups: Interest group corporatism and democratic theory (master's thesis). Simon Fraser University, British Columbia, Kanada.

Dewi, K.H. (2007). Demokratisasi dan dekonstruksi ideologi gender Orde Baru. Jurnal Penelitian Politik, 4(1), 59-67.

Dewi, K.H. (2015). Indonesian women and local politics: Islam, gender and networks in post-Suharto Indonesia. Singapore: NUS Press.

Gerber, L.G. (1995). Corporatism and state theory: A review essay for historians. Social Science History, 19(3), 313-332. doi: https:// 
doi.org/10.1017/S0145553200017399.

Handayani, T., Parimartha, M.A., P., Sukesi, M.S., P., \& Ardika, M.A., P. (2008). Pemberdayaan dan Kesejahteraan Keluarga (PKK) di kota Malang dalam perspektif kajian budaya. E-Journal of Cultural Studies, 2(1), 1-14. Retrieved from https://ojs.unud.ac.id/index. $\mathrm{php} / \mathrm{ecs} / \mathrm{article} / \mathrm{view} / 3558$.

MacIntyre, A. (1994). Organising interests: Corporatism in Indonesian politics. Retrieved from Murdoch University Website: https:// www.murdoch.edu.au/Research-capabilities/Asia-ResearchCentre/_document/working-papers/WP43.pdf.

Malik, A., Yohanes, D., Pitaloka, D.A., Widianto, E., Istiawan, H., Fauzi, I., \& Zainudin, M. (2013). Tolak uangnya, pilih yang jujur: Pengalaman advokasi pendidikan pemilih. Malang: Malang Corruption Watch.

Milne, S. (1983). Corporatism in the ASEAN countries. Contemporary Southeast Asia, 5(2), 172-184. Retrieved from https://www.jstor. org/stable/25797757?seq=1.

Nurcholis, H. (2016, 8 June). Desa, korporasi negara yang keberatan beban. Media Indonesia. Retrieved from http://www.mediaindonesia. com

Rahayu, R.I. (2005, November 19). Militerisme Orde Baru dan ideologi koncowingking, pengukuhan ideologi perempuan Indonesia secara pemaknaan ksatria jawa. Retrieved from https:// www.academia.edu/1581472/Militerisme_dan_Ideologi_ Koncowingking?auto=download

Reeve, D. (1985). Golkar of Indonesia: An alternative to the party system. Singapore: Oxford University Press.

Robinson, K.M., \& Bessell, S. (eds.). (2002). Women in Indonesia: Gender, equity, and development. Singapore: ISEAS.

Roniger, L. (2004). Political clientelism, democracy, and market economy. Comparative politics, 36 (3), 353-375. Retrieved from http://www. rochelleterman.com/ComparativeExam/sites/default/files/ Bibliography\%20and\%20Summaries/Comparative\%20Politics_0. pdf.

Rosser, A., Roesad, K., \& Edwin, D. (2004). Indonesia: The politics of inclusion. Retrieved from https://opendocs.ids.ac.uk/opendocs/ bitstream/handle/123456789/4068/Wp229.pdf.

Schmitter, P. C. (1974). Still the century of corporatism?. The Review of Politics, 36, 85-131. doi: https://doi.org/10.1017/ 
S0034670500022178.

Soebhan, S.R. (2000). Model reformasi birokrasi Indonesia. Retrieved from https://abu4faqih.files.wordpress.com/2011/01/modelreformasi-birokrasi.pdf.

Soetjipto, A.W., \& Adelina, S. (2013). Suara dari desa: menuju revitalisasi PKK. Tangerang: Marjin Kiri.

Sofi'i, M. (2015, March 18). Pertumbuhan ekonomi batu menggembirakan, lebih tinggi dari Jatim. Surabaya Bisnis. Retrieved from http:// surabaya.bisnis.com

Stokes, S.C., Dunning, T., Nazareno, M., \& Brusco, V. (2013). Brokers, voters, and clientelism: The puzzle of distributive politics. Cambridge: Cambridge University Press.

Suryakusuma, J. (2011). Ibuisme negara: Konstruksi sosial keperempuanan Orde Baru. Depok: Komunitas Bambu.

Wang, C-S., \& Kurzman, C. (2007). Dilemmas of electoral clientelism: Taiwan, 1993. International Political Science Review, 28(2), 225245. doi: 10.1177/0192512107075408.

Wiarda, H.J. (2009). The political sociology of a concept: Corporatism and the "distinct tradition". The Americas, 66, 81-106. doi: 10.1353/ tam.0.0155.

Wulan, T.R. (2008). Pemetaan gerakan perempuan di Indonesia dan implikasinya terhadap penguatan public sphere di pedesaan. Jurnal Studi Gender \& Anak, 3(1), 120-139. Retrieved from https://yinyangstain.files.wordpress.com/2009/01/9-tyas-retnowulan-pemetaan-gerakan-perempuan-di-indonesia.pdf.

Zaenurullah, L., Boedijono, B., \& Suryawati, D. (2015). Pertumbuhan ekonomi kota Batu sebagai daerah otonom baru. E-Sospol, 2(1), 12-18. Retrieved from https://jurnal.unej.ac.id/index.php/ESOS/article/view/5692. 